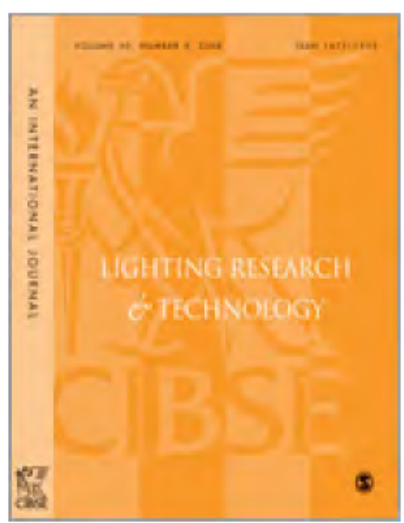

\title{
Correspondence: Daylighting: Why infra-red should be explored.
}

\begin{tabular}{|c|c|}
\hline Journal: & Lighting Research \& Technology \\
\hline Manuscript ID & LRT-19-0153.R1 \\
\hline Manuscript Type: & Review \\
\hline $\begin{array}{r}\text { Date Submitted by the } \\
\text { Author: }\end{array}$ & 12-Oct-2019 \\
\hline Complete List of Authors: & Veto, Peter; Ulm University, Psychology \\
\hline Keywords: & daylighting, non-visual effects, infra-red \\
\hline Abstract: & (Due to the brevity and nature of the paper, no abstract is provided.) \\
\hline
\end{tabular}

\section{SCHOLARONE" Manuscripts}




\section{Correspondence: Daylighting: Why infra-red should be explored.}

In their recent paper, Knoop et al' present a convincing case for daylighting. In agreement with a contemporary understanding of the role of lighting, ${ }^{2}$ their analysis goes beyond the strictly perceptual effects of light on humans, as well as the spectral boundaries of visible radiation. They mention the importance of vitamin $\mathrm{D}$ production, which is linked to UVB exposure. ${ }^{3}$ They also discuss thermal properties of infra-red (IR) radiation and define the long end of daylight's wavelength spectrum as $\sim 2600 \mathrm{~nm}$. More importantly, they elaborate on circadian entrainment and the invigorating effects of shortwavelength light, pointing out that while relevant studies usually employ electric sources, natural light should likewise provide these benefits through potentially high intensity and colour temperature.

Some noted ramifications of daylighting, however, remain without physiological explanation in their paper. Although the existence of purely psychological effects or a nonphysical property ${ }^{1,4}$ of sunshine are intriguing propositions, low-level explanations ought to provide a better ground for empirical inquiry. While the visible spectrum can also differ in many details between electric and natural light, the IR portion is insignificant in the most commonly used fluorescent and LED lamps and always present in daylight, thereby being a reasonable suspect for the source of differences in observed effects. Indeed, a large body of literature demonstrates connections between long-wavelength radiation and basic physiological functions, possibly in line with the acclaimed advantages of daylighting 1 regarding retinal functions ${ }^{5-11}$ or increased glare tolerance ${ }^{12,13}$ and overall comfort. ${ }^{14-16}$ Grasping the potential connection between these benefits of daylight and the existing knowledge on low-level effects of IR radiation would require targeted experimental testing, and until then, contemplating such a link remains theoretical. Adding to the uncertainty, most of our insight into the physiological significance of various long wavelengths comes from studies on animal models. Furthermore, thermal effects of IR in natural light can have a negative impact on comfort and adding IR to existing electric light sources would greatly decrease their energy efficiency. Therefore, the aim of this letter is not to directly promote the use of IR in general lighting. Instead, the following points are made to draw attention to some, often neglected, non-visual effects of red and IR radiation. These effects might play 
a role in daylighting, deserve further study, and could possibly be utilized in specific lighting applications.

Red and near infra-red (NIR) exposure influences eye health, ${ }^{17-25}$ mood and neuropsychological well-being, ${ }^{26,27}$ and has various further clinical effects. ${ }^{28-36}$ While some medical applications aim for short and intense treatments, the most efficient use of red and NIR for health purposes appears to be at low irradiation levels over long durations. ${ }^{37}$ These levels are still generally higher than that of daylight NIR irradiance, but the ranges are overlapping. ${ }^{37,38}$ Daylight might also be relevant in longer time frames (e.g., across years), can cover larger surface area, and includes far infra-red radiation that has possibly similar effects ${ }^{39,40}$ to those of NIR. Comparing various application scenarios is further complicated by that irradiance and dosage on a given anatomical structure depend on its distance from the surface. The extent of this is not easily quantifiable, as beyond the power-independent attenuation in various kinds of tissue, ${ }^{41}$ systemic effects are instrumental as well. ${ }^{42}$ Implications for the skin and the eye are nevertheless consequential even at low irradiance levels. ${ }^{43}$ Similarly to beneficial properties, these are the locations where harmful effects of light are most detectable. NIR radiation can contribute to photoaging and cause thermal damage at higher intensities, although this does not immediately translate to a general need for skin protection. ${ }^{44,45}$

Effects of various parts of the spectrum are also in interaction with each other. For example, exposure to NIR radiation can aid in the recovery from damage induced by shorter wavelengths. ${ }^{46-49}$ Due to mechanisms based on chromatic aberration, narrow-band light of both short and long wavelengths, or a lack of either part of the visible spectrum, can disrupt emmetropization. ${ }^{50-52}$ These observations speak for daylighting, where the ratio of various wavelengths is balanced. They also allude to new possibilities for healthoriented applications by means of electric lighting, given that the underlying processes are sufficiently understood.

A fascinating and so far largely unexplored question is whether different narrowband portions within the NIR spectrum have disparate physiological effects. Pioneering research from the lab of Maik Hüttemann indicates that this might indeed be the case: even antagonistic effects can be achieved by choosing different, yet not too distant, wavelengths. ${ }^{53}$ On the one hand, these oppositions are likely balanced out when the whole 
spectrum is present - making the effects of daylight even more difficult to compare to those of most laboratory-based experiments. On the other hand, understanding the mechanisms behind them could open up novel ways to utilize narrow-band LED sources.

Contemporary lighting places much emphasis on human well-being and the nonvisual effects of light. Despite this, the ever-growing amount of empirical and theoretical knowledge about the physiological effects of various wavelengths around and beyond red has not yet found its place in the conversation about lighting practices. These effects show some resemblance to those of daylight, while dosage and other considerations are difficult to quantitatively compare between the various light sources and applications. Adding to the complexity, different narrow-band regions of NIR can even have contrasting physiological effects, and complementary interactions between short and long wavelengths are known to affect developmental and recovery processes in the retina. These observations lend further support to daylighting, where such interactions are presumably well-balanced. They also show that interdisciplinary study and discussion of the physiological effects of red and NIR radiation is necessary for the evaluation of lighting practices. 


\section{References}

1 Knoop M, Stefani O, Bueno B, Matusiak B, Hobday R, Wirz-Justice A, Martiny K, Kantermann T, Aarts MP, Zemmouri N, Appelt S. Daylight: What makes the difference? Lighting Research and Technology First published 201923 July,2019. DOI: 1477153519869758.

2 Boyce PR. Lighting research for interiors: the beginning of the end or the end of the beginning. Lighting Research and Technology 2004; 36(4): 283-293.

3 Holick MF, MacLaughlin JA, Clark MB, Holick SA, Potts JT, Anderson RR, Blank IH, Parrish JA, Elias P. Photosynthesis of previtamin D3 in human skin and the physiologic consequences. Science 1980; 210(4466): 203-205.

4 Ne'eman E, Craddock J, Hopkinson RG. Sunlight requirements in buildings-I. Social survey. Building and Environment 1976;11(4): 217-238.

5 Hobday R. Myopia and daylight in schools: a neglected aspect of public health? Perspectives in Public Health 2016; 136(1): 50-55.

6 French AN, Ashby RS, Morgan IG, Rose KA. Time outdoors and the prevention of myopia. Experimental Eye Research 2013; 114: 58-68.

7 Chakraborty R, Ostrin LA, Nickla DL, Iuvone PM, Pardue MT, Stone RA. Circadian rhythms, refractive development, and myopia. Ophthalmic and Physiological Optics 2018; 38(3): 217-245.

8 Cui D, Trier K, Ribel-Madsen SM. Effect of day length on eye growth, myopia progression, and change of corneal power in myopic children. Ophthalmology 2013; 120(5): 1074-1079.

9 Lagrèze WA, Schaeffel F. Preventing myopia. Deutsches Ärzteblatt International 2017; 114(35-36): 575.

10 Reimchen TE. Human color vision deficiencies and atmospheric twilight. Social Biology 1987; 34(1-2): 1-11.

11 Laeng B, Brennen T, Elden Å, Paulsen HG, Banerjee A, Lipton R. Latitude-of-birth and season-of-birth effects on human color vision in the Arctic. Vision Research 2007; 47(12): 1595-1607.

12 Heerwagen JH, Zagreus L. The Human Factors of Sustainable Building Design: Post Occupancy Evaluation of the Philip Merrill Environmental Center. Report, University of California, 2005. Retrieved 25 September 2019, from https://escholarship.org/uc/item/67j1418w 
13 Chauvel P, Collins JB, Dogniaux R, Longmore J. Glare from windows: Current views of the problem. Lighting Research and Technology 1982; 14(1): 31-46.

14 Chinazzo G, Pastore L, Wienold J, Andersen M. A field study investigation on the influence of light level on subjective thermal perception in different seasons. In: Proceedings of 10th Windsor Conference: Rethinking Comfort, Windsor, UK: 15 April, 2018. Network for Comfort and Energy Use in Buildings (NCEUB), 2018.

15 Kahn Jr PH, Severson RL, Ruckert JH. The human relation with nature and technological nature. Current Directions in Psychological Science 2009; 18(1): 37-42.

16 Kahn Jr PH, Friedman B, Gill B, Hagman J, Severson RL, Freier NG, Feldman EN, Carrère S, Stolyar A. A plasma display window?-The shifting baseline problem in a technologically mediated natural world. Journal of Environmental Psychology 2008; 28(2): 192-199.

17 Kaynezhad P, Tachtsidis I, Jeffery G. Optical monitoring of retinal respiration in real time: $670 \mathrm{~nm}$ light increases the redox state of mitochondria. Experimental Eye Research 2016; 152: 88-93.

18 Sivapathasuntharam C, Sivaprasad S, Hogg C, Jeffery G. Improving mitochondrial function significantly reduces the rate of age related photoreceptor loss. Experimental Eye Research 2019, DOI: 107691.

19 Kokkinopoulos I, Colman A, Hogg C, Heckenlively J, Jeffery G. Age-related retinal inflammation is reduced by $670 \mathrm{~nm}$ light via increased mitochondrial membrane potential. Neurobiology of Aging 2013; 34(2): 602-609.

20 Gkotsi D, Begum R, Salt T, Lascaratos G, Hogg C, Chau KY, Schapira AH, Jeffery G. Recharging mitochondrial batteries in old eyes. Near infra-red increases ATP. Experimental Eye Research 2014; 122: 50-53.

21 Geneva II. Photobiomodulation for the treatment of retinal diseases: A review. International Journal of Ophthalmology 2016; 9(1): 145-152.

22 Ivandic BT, Ivandic T. Low-level laser therapy improves vision in patients with age-related macular degeneration. Photomedicine and Laser Surgery 2008; 26(3): 241-245.

23 Merry GF, Munk MR, Dotson RS, Walker MG, Devenyi RG. Photobiomodulation reduces drusen volume and improves visual acuity and contrast sensitivity in dry age related macular degeneration. Acta Ophthalmologica 2017; 95(4): e270-277.

24 Eells JT, Wong-Riley MT, VerHoeve J, Henry M, Buchman EV, Kane MP, Gould LJ, Das R, Jett M, Hodgson BD, Margolis D. Mitochondrial signal transduction in accelerated wound and retinal healing by near-infrared light therapy. Mitochondrion 2004; 4(5-6): 559-567. 
25 Ivandic BT, Ivandic T. Low-level laser therapy improves visual acuity in adolescent and adult patients with amblyopia. Photomedicine and Laser Surgery 2012; 30(3): 167-171.

26 Barrett DW, Gonzalez-Lima F. Transcranial infrared laser stimulation produces beneficial cognitive and emotional effects in humans. Neuroscience 2013; 230: 13-23.

27 Schiffer F, Johnston AL, Ravichandran C, Polcari A, Teicher MH, Webb RH, Hamblin MR. Psychological benefits 2 and 4 weeks after a single treatment with near infrared light to the forehead: A pilot study of 10 patients with major depression and anxiety. Behavioral and Brain Functions 2009; 5(1): 46.

28 Ferraresi C, Hamblin MR, Parizotto NA. Low-level laser (light) therapy (LLLT) on muscle tissue: Performance, fatigue and repair benefited by the power of light. Photonics and Lasers in Medicine 2012; 1(4): 267-286.

29 Bjordal JM, Bensadoun RJ, Tunèr J, Frigo L, Gjerde K, Lopes-Martins RA. A systematic review with meta-analysis of the effect of low-level laser therapy (LLLT) in cancer therapyinduced oral mucositis. Supportive Care in Cancer 2011; 19(8): 1069-1077.

30 Avci P, Nyame TT, Gupta GK, Sadasivam M, Hamblin MR. Low level laser therapy for fat layer reduction: A comprehensive review. Lasers in Surgery and Medicine 2013; 45(6): 349357.

31 Lopes-Martins RA, Penna SC, Joensen J, Vereid Iversen V, Magnus Bjordal J. Low level laser therapy [LLLT] in inflammatory and rheumatic diseases: A review of therapeutic mechanisms. Current Rheumatology Reviews 2007; 3(2): 147-154.

32 Carroll JD, Milward MR, Cooper PR, Hadis M, Palin WM. Developments in low level light therapy (LLLT) for dentistry. Dental Materials 2014; 30(5): 465-475.

33 Obradović RR, Kesić LG, Peševska S. Influence of low-level laser therapy on biomaterial osseointegration: A mini-review. Lasers in Medical Science 2009; 24(3): 447-451.

34 Strubakos CD, Malik M, Wider JM, Lee I, Reynolds CA, Mitsias P, Przyklenk K, Hüttemann M, Sanderson TH. Non-invasive treatment with near-infrared light: A novel mechanismsbased strategy that evokes sustained reduction in brain injury after stroke. Journal of Cerebral Blood Flow and Metabolism 2019, DOI: 0271678X19845149.

35 Odinokov D, Hamblin MR. Aging of lymphoid organs: Can photobiomodulation reverse age-associated thymic involution via stimulation of extrapineal melatonin synthesis and bone marrow stem cells? Journal of Biophotonics 2018; 11(8): e201700282.

36 Desmet KD, Paz DA, Corry JJ, Eells JT, Wong-Riley MT, Henry MM, Buchmann EV, Connelly MP, Dovi JV, Liang HL, Henshel DS. Clinical and experimental applications of NIR-LED photobiomodulation. Photomedicine and Laser Therapy 2006; 24(2): 121-128. 
37 Chung H, Dai T, Sharma SK, Huang YY, Carroll JD, Hamblin MR. The nuts and bolts of low-level laser (light) therapy. Annals of Biomedical Engineering 2012; 40(2): 516-533.

38 Piazena H, Kelleher DK. Effects of infrared A irradiation on skin: Discrepancies in published data highlight the need for an exact consideration of physical and photobiological laws and appropriate experimental settings. Photochemistry and Photobiology 2010; 86(3): 687-705.

39 Shui S, Wang X, Chiang JY, Zheng L. Far-infrared therapy for cardiovascular, autoimmune, and other chronic health problems: A systematic review. Experimental Biology and Medicine 2015; 240(10): 1257-1265.

40 Vatansever F, Hamblin MR. Far infrared radiation (FIR): Its biological effects and medical applications. Photonics and Lasers in Medicine 2012; 1(4): 255-266.

41 Enwemeka CS. Attenuation and penetration of visible $632.8 \mathrm{~nm}$ and invisible infra-red 904nm light in soft tissues. Laser Therapy 2000; 13(1): 95-101.

42 Lima AA, Spínola LG, Baccan G, Correia K, Oliva M, Vasconcelos JF, Soares MB, Reis SR, Medrado AP. Evaluation of corticosterone and IL-1 $\beta$, IL-6, IL-10 and TNF- $\alpha$ expression after 670-nm laser photobiomodulation in rats. Lasers in Medical Science 2014; 29(2): 709715.

43 Rojas JC, Gonzalez-Lima F. Low-level light therapy of the eye and brain. Eye and Brain 2011; 3: 49-67.

44 Robert C, Bonnet M, Marques S, Numa M, Doucet O. Low to moderate doses of infrared A irradiation impair extracellular matrix homeostasis of the skin and contribute to skin photodamage. Skin Pharmacology and Physiology 2015; 28(4): 196-204.

45 Diffey B, Cadars B. An appraisal of the need for infrared radiation protection in sunscreens. Photochemical and Photobiological Sciences 2016; 15(3): 361-364.

46 Albarracin R, Eells J, Valter K. Photobiomodulation protects the retina from light-induced photoreceptor degeneration. Investigative Ophthalmology and Visual Science 2011; 52(6): 3582-3592.

47 Qu C, Cao W, Fan Y, Lin Y. Near-infrared light protect the photoreceptor from light-induced damage in rats. In Retinal Degenerative Diseases. Springer, New York, NY, 2010.

48 Eells JT, DeSmet KD, Kirk DK, Wong-Riley M, Whelan HT, Ver Hoeve J, Nork TM, Stone J, Valter K. Photobiomodulation for the treatment of retinal injury and retinal degenerative diseases. In Proceedings of Light-Activated Tissue Regeneration and Therapy Conference, $\mathrm{R}$ Waynant and DB Tata (eds). Boston, MA: Springer, 2008: pp. 39-51 
49 Albarracin R, Valter K. 670 nm red light preconditioning supports Müller cell function: Evidence from the white light induced damage model in the rat retina. Photochemistry and Photobiology 2012; 88(6): 1418-1427.

50 Rucker FJ. The role of luminance and chromatic cues in emmetropisation. Ophthalmic and Physiological Optics 2013; 33(3): 196-214.

51 Troilo D, Smith EL, Nickla DL, Ashby R, Tkatchenko AV, Ostrin LA, Gawne TJ, Pardue MT, Summers JA, Kee CS, Schroedl F. IMI-report on experimental models of emmetropization and myopia. Investigative Ophthalmology and Visual Science 2019; 60(3): M31-88.

52 Gawne TJ, Siegwart Jr JT, Ward AH, Norton TT. The wavelength composition and temporal modulation of ambient lighting strongly affect refractive development in young tree shrews. Experimental Eye Research 2017; 155: 75-84.

53 Sanderson TH, Wider JM, Lee I, Reynolds CA, Liu J, Lepore B, Tousignant R, Bukowski MJ, Johnston H, Fite A, Raghunayakula S. Inhibitory modulation of cytochrome c oxidase activity with specific near-infrared light wavelengths attenuates brain ischemia/reperfusion injury. Scientific Reports 2018; 8(1): 3481.

\section{$P$ Veto $P h D$}

General Psychology, Ulm University, UIm, Germany

Email:peter.veto@uni-ulm.de

ORCiD: https://orcid.org/0000-0003-3545-0098 